\title{
Correction to: RNA sequencing identifies novel non-coding RNA and exon-specific effects associated with cigarette smoking
}

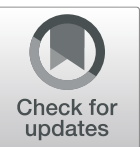

Margaret M. Parker ${ }^{1,2}$, Robert P. Chase ${ }^{1}$, Andrew Lamb ${ }^{1}$, Alejandro Reyes ${ }^{3}$, Aabida Saferali, ${ }^{1,2}$, Jeong H. Yun ${ }^{1,4}$, Blanca E. Himes ${ }^{5}$, Edwin K. Silverman ${ }^{1,2,4}$, Craig P. Hersh ${ }^{1,2,4}$ and Peter J. Castaldi 1,2,6*

\section{Correction to: BMC Med Genomics (2017) 10:58 https://doi.org/10.1186/s12920-017-0295-9}

Following publication of the original article [1], the authors provided an updated accession number in the "Availability of data and materials" section of the declarations. The accession number is listed as GSE9753, but the correct number is GSE97531.

\footnotetext{
Author details

'Channing Division of Network Medicine, Brigham and Women's Hospital, 181 Longwood Ave, Boston, MA, USA. ${ }^{2}$ Harvard Medical School, Boston, MA 02115, USA. ${ }^{3}$ Department of Biostatistics and Computational Biology, Dana-Farber Cancer Institute, Boston, MA, USA. ${ }^{4}$ Division of Pulmonary and Critical Care Medicine, Brigham and Women's Hospital, Boston, MA, USA. ${ }^{5}$ Department of Biostatistics, Epidemiology, and Informatics, Perelman School of Medicine, University of Pennsylvania, Philadelphia, PA, USA. ${ }^{6}$ Division of General Internal Medicine and Primary Care, Brigham and Women's Hospital, Boston, MA, USA.
}

Published online: 18 November 2019

\section{Reference}

1. Parker, et al. RNA sequencing identifies novel non-coding RNA and exonspecific effects associated with cigarette smoking. BMC Med Genomics. 2017;10:58. https://doi.org/10.1186/s12920-017-0295-9.

The original article can be found online at https://doi.org/10.1186/s12920017-0295-9

* Correspondence: repjc@channing.harvard.edu

${ }^{1}$ Channing Division of Network Medicine, Brigham and Women's Hospital,

181 Longwood Ave, Boston, MA, USA

${ }^{2}$ Harvard Medical School, Boston, MA 02115, USA

Full list of author information is available at the end of the article

(c) The Author(s). 2019 Open Access This article is distributed under the terms of the Creative Commons Attribution 4.0 International License (http://creativecommons.org/licenses/by/4.0/), which permits unrestricted use, distribution, and reproduction in any medium, provided you give appropriate credit to the original author(s) and the source, provide a link to the Creative Commons license, and indicate if changes were made. The Creative Commons Public Domain Dedication waiver (http://creativecommons.org/publicdomain/zero/1.0/) applies to the data made available in this article, unless otherwise stated. 